\title{
Perspektive vaspitanja djece jasličke dobi u Bosni i Hercegovini
}

\author{
Aleksandra Šindić \\ Univerzitet u Banjoj Luci \\ aleksandra.sindic-radic@ff.unibl.org
}

Uočavajući protivrječnosti između savremenih naučnih istraživanja i trendova koji ukazuju na presudan uticaj ranog djetinjstva i podrške najmlađoj djeci za razvoj čovjeka i prosperitet društva i zbilje u predškolstvu u Bosni i Hercegovini kao zemlji u tranziciji i poslijeratnim godinama, pristupilo se istraživanju. Kvalitativnim istraživanjem putem SWOT-analize, ulazeći u polje pedagoške futurologije, nastojalo se istražiti i dugoročno sagledati, iz vaspitačkog ugla, strateške komponente razvoja i organizovanja predškolskog vaspitanja djece prvog starosnog doba (do tri godine) u BiH. Istraživački cilj je sagledavanje vizije vaspitača, razumijevanje misije vrtića, te ukazivanje na interne i eksterne mogućnosti i ograničenja za optimalno vaspitanje djece prvog starosnog doba (do tri godine). Kao glavno polje djelovanja predškolskih radnika za unapređenje podrške dječijem razvoju, pored dodatnog stručnog usavršavanja i istraživanja, osavremenjavanja i obogaćivanja vaspitne prakse s bebama, ističe se i promovisanje struke i vlastitog rada kao i senzibiliranje društva o značaju ranog djetinjstva.

Ključne reči: vaspitanje, predškolska djeca prvog starosnog doba, jednake mogućnosti

\section{Uvod}

Tokom prošlog i ovog vijeka, naučnici različitih profila, pedagozi, psiholozi, neurolozi, ekonomisti i dr. putem svojih istraživanja žele da sagledaju i objasne značaj najranijeg djetinjstva. Da je beba ta koja stvara čovjeka, da smo mi ono što je beba izgradila u prve dvije godine naglasila je još ljekar i pedagog Marija Montessori početkom prošlog vijeka, uočavajući snagu i konstruktivnu energiju nesvjesnog upijajućeg uma malog djeteta (Montessori 2003; Kordeš Demšar 2007, 80-81). lako dijete samo sebe stvara čovjekom, iako okolina (socijalna i materijalna) ništa ne kreira, ona može da podstiče, da ometa i čak da deformiše dječiji razvoj. Zato se Marija Montessori sa posebnom pažnjom ophodi prema prvim godinama djetetovog života i vaspitanju najmlađih u montessori ustanovama. Emmi Pikler, pedijatrica i pedagog, po drugom svjetskom ratu, daje smjernice za njegu jasličke djece (Gerber $\mathrm{i}$ Johnson 1997). Hranjenje, presvlačenje, uspavljivanje su intimne aktivnosti u kojima beba treba da se osjeća ugodno i da razvija povjerenje u odraslog. Od- 
rasli nije tu da prestimuliše bebe nego da podrži razvoj pokreta i inicijative (Šindić 2018, 24). Piklerova smatra da je za razvoj bebe presudan odnos koji razvija odrasli dok je njeguje. Značaj interpersonalnih odnosa bebe sa majkom (ili zamjenom za majku) u svojoj teoriji afektivne vezanosti predočava psihoanalitičar John Bowlby (Bowlby 1995) početkom druge polovine prošlog vijeka. Istovremeno, Erik Bern, tvorac transakcione analize naglašava da je socijalno stimulisanje razvojna potreba svakog djeteta (Jovanović Magyar 2008). Uporedo sa ovim nalazima, neurolog Marien Diamond otkriva mogućnosti poboljšanja mozga mladunaca kroz evolutivno-podržavajuće aktivnosti (Diamond 2001). Danas, zahvaljujući razvoju nauke i tehnologije, možemo da provirimo u ljudski mozak, da sagledamo aktivnost dječijeg upijajućeg uma, razvoj sinapsi i neuro-puteva te uočimo spoljnji uticaju na dozrijevanje dječijih nervnih mijelinskih omotača, što i medicinski dokazuje napredne pedagoške i psihološke promisli iz prošlog vijeka. Neuronauke u interdisciplinarnom pristupu s pedagogijom utiču na sagledavanje i iznalaženje evolutivno-podržavajućih aktivnosti za razvoj djece provog starosnog doba (Rajović 2010; Rajović, Šindić i Čampara 2014; Rajović, Šindić i Suzić 2015). Danas znamo da na razvoj beba utiču naslijeđe, aktivnost same bebe, sredina (socijalna i materijalna) i interakcija s njom i da je to presudan period u životu.

Zato nisu iznenađujući rezultati ekonomskih istraživanja Jamesa Heckmana (2013), jer ukazuju da je novac uložen u predškolsko vaspitanje djece najbolje investirani kapital svake države. Djeca se optimalno razvijaju i kao izgrađeni pojedinci svojim radom više doprinose boljitku društva i ostvarenju državnog kapitala. James Heckman objasnio je da je najviši povrat novca od ulaganja u djecu najranije dobi (od rođenja do tri godine), a posebno za djecu iz materijalno ili socijalno depriviranih porodica. Ako se s ulaganjima počne tek sa tri ili četiri godine već je puno propušteno jer se vještine stiču na komplementaran i dinamičan način (Heckman 2013). Autor zaključuje da bi se najveća pažnja i napori trebali usmjeriti na kvalitetan razvoj u ranom djetinjstvu, a posebno na institucionalizovano vaspitanje dojenčadi i djece do tri godine iz depriviranih porodica pošto se na taj način amortizuju negativne porodične prilike i omogućava bolji razvoj. Danas je predškolskim vaspitanjem i obrazovanjem obuhvaćen veliki broj mališana, a širom svijeta postoje uspješni i brojni rani kompenzatorski programi koji podržavaju djecu čije su porodične prilike neadekvatne (Barnett 2008; Stojaković 2000).

\section{Predškolci i predškolstvo u Bosni i Hercegovini danas}

Bosna i Harcegovina je zemlja u tranziciji u poslijeratnim godinama, pogođena teškom ekonomskom, socijalnom i političkom krizom. Cjelokupna dru- 
štvena situacija se odražava na život najmlađih članova društva. Ono što najviše zabrinjava je dječije siromaštvo.

Kriza u zemlji i siromaštvo više obuhvata djecu nego ostatak stanovništva. Ako još tome pridodamo rezultate savremenih istraživanja o dječijem razvoju, možemo nažalost zaključiti, da su najmlađa djeca najranjivija i najviše pogođeni članovi društva države Bosne i Hercegovine. Studije pokazuju da $28 \%$ stanovništva u BiH u 2016. godini živi ispod granice siromaštva ( $\mathrm{Pa}$ pić 2017). Djeca koja žive u većim porodicama su najzastupljenija među siromašnom djecom u poređenju sa opštom populacijom (Iniciativa za bolju i humaniju inkluziju 2013). Tri četvrtine sve siromašne djece živi u ruralnim područjima (74\%). Podaci Agencije za statistiku BiH ukazuju da u vrtić idu djeca roditelja koji nisu siromašni, iz porodica gdje oba roditelja rade $(75,5 \%)$, dok manje od $2 \%$ nezaposlenih roditelja, a samo $0,5 \%$ djece sa sela. Sve to ukazuje na velike razlike i nejednaka mogućnosti.

Druga otežavajuća okolnost jeste i nerazvijenost mreže predškolskih ustanova u Bosni i Hercegovini. 2013. godine je po istraživanjima koje je izveo UNICEF ova zemlja imala najmanji obuhvat djece predškolskim vaspitanjem i obrazovanjem od svih evropskih i srednjoazijskih država (Camović i Hodžić 2017, 34). Obuhvat djece koja su išla u predškolske ustanove 2017/2018 radne godine u Bosni i Hercegovini je iznosio 25889 djece uzrasta od jedne do šest godina što je 13,98\% ukupne djece tog uzrasta u državi (Agencija za statistiku Bosne i Hercegovine 2017; 2018). Za djecu koja kreću u školu, a nisu obuhvaćena redovnim vrtićkim programom organizuje se Program pripreme za školu koji je obavezan i traje tri mjeseca (Okvirni zakon o predškolskom odgoju i obrazovanju u Bosni i Hercegovini 2018, 16 član). Njime se ublažava ovako slab obuhvat djece (Camović i Hodžić 2017, 32). Uprotekloj radnoj 2017/2018 godini vrtiće u BiH je pohađalo 5023 djeteta do tri godine starosti što je 4,44\% od ukupnog broja djece tog uzrasta. Od toga je 232 djeteta uzrasta do godinu dana, 1872 od godine do dvije, a 2780 od dvije do tri godine (Agencija za statistiku Bosne i Hercegovine 2017; 2018). Za poređenje dajemo podatke o procentu obuhvata djece do tri godine u evropskim zemljama prije osam godina. Evropska komisija i SURS su u 2011. godini izračunali da je obuhvat djece do tri godine institucioanlizovanim programom u Danskoj iznosio $74 \%$ djece, u Sloveniji 55,6\%, Holandiji $52 \%$, Švedskoj $51 \%$, Francuskoj i Luksemburgu $44 \%$, Islandu, Belgiji i Španiji $39 \%$... dok je manji bio u Hrvatskoj $15 \%$, Austriji 14\%, Malti 11\%, Mađarskoj $8 \%$, u Češkoj $5 \%$, Slovačkoj 4 \%, Poljskoj 3 \% i Rumuniji 2 \% (Hočevar i Kovač Šebart 2017). U radnoj 2017/18. po podacima do kojih je došao SURS u Republici Sloveniji je institucionalizovanim predškolskim vaspitanjem obuhvaćeno $63,5 \%$ djece do 
tri godine. lako Ustav Bosne i Hercegovine (1995) obavezuje poštovanje dječijih prava u skladu sa Konvencijom o ljudskim pravima (1950) i Konvencijom UN o pravima djeteta (1989) gdje se pravo na obrazovanje smatra progresivnim pravom, moglo bi se reći da je Bosna i Hercegovina još daleko od željene realizacije.

U Bosni i Hercegovini većina predškolskih ustanova (javnih i privatnih) radi po entitetskim programima i vrlo neujednačeno. U Republici Srpskoj službeni dokument je Program predškolskog vaspitanja i obrazovanja (2007) gdje postoje posebne upute za rad (njega, vaspitanje i obrazovanje) sa djecom jasličkog uzrasta.

Da bismo bolje razumjeli današnje predškolsto u BiH, a viziju i misiju predškolstva (sa posebnim osvrtom na bebe) sagledali očima vaspitača, realizovala sam SWOT analizu s vaspitačima i stručnim saradnicima u banjalučkim vrtićima.

\section{Metod}

U ovome radu sam putem kvalitativnog futurološkog istraživanja nastojala sagledati vrtićku realnost, ali i njenu idelnu projekciju u budućnosti. Futurološka istraživanja ukazuju da je budućnost predvidljiva, a možemo je spoznati kao moguću prije nego li unaprijed datu i programiranu (Suzić 2012). Vrtićka stvarnost može se gledati kao kompleksan i dinamičan socijalni entitet (Slunjski 2011) koji se neprestano razvija. Različiti ljudi na različite načine tumače objektivnu stvarnost (Jovanović Magyar 2008; Stewart i Joins 2011; Slunjski 2011). Kvalitativna istraživanja nastoje razumjeti značenje koje ljudi pripisuju pojedinim fenomenima i odnosima, a tehnike koje koristi su fleksibilne i osjetljive na socijalni kontekst. Ovakva istraživanja uključuju empatički uvid, socijalo kontekstualnu osjetljivost, naglasak na procesu i promjenama, autentično viđenje učesnika, direktan kontakt istraživača s problemom, a vaspitač ne samo da može, već je i poželjno da bude istraživač vlastite prakse. Da bih zajedno s vaspitačima evaluirala prednosti, slabosti, mogućnosti i prepreke ostvarenja idelano organizovanog i realizovanog predškolskog vaspitanja za djecu do tri godine u BiH primjenila sam kvalitativnu analitičku metodu SWOT-analizu s futurološkim elementima. Putem SWOT analize vaspitači su postali istraživači vlastite prakse kroz proces dugoročnog sagledavanja uloge predškolstva, uz iznalaženje ideja i elemenata planiranja i kreiranja strategija razvoja.

Predmet istraživanja se odnosi na dugoročno sagledavanje podržavajućeg vaspitanja djece do tri godine iz ugla vaspitača.

Istraživački cilj je utvrđivanje vizije vaspitača, misije vrtića, te internih i ek- 
sternih mogućnosti i ograničenja za postizanje optimalnog vaspitanja djece do tri godine.

Istraživanje je realizovano u mjesecu januaru 2019. godine na uzorku - fokus grupi od trideset praktičara - vaspitačica i stručnih saradnica Javne ustanove Centra za predškolsko vaspitanje i obrazovanje iz tri banjalučka vrtića Kolibri, Lana i Plavi čuperak.

Pri istraživačkoj proceduri prvi korak je bio da se ustanovi kako vaspitačice sebi predočavaju idealnu organizaciju vaspitno-obrazovnog rada s djecom do tri godine - tj. da se odredi njihova vizija optimalne podrške razvoju djece do tri godine starosti. Drugi korak se odnosio na sagledavanje i razumijevanje uloge vrtića u tome, uzimajući u obzir i širi društveni kontekst u kojem ustanova djeluje. Sljedeća četiri koraka predstavljaju vaspitačku analizu vrtićkih i širih društvenih faktora koji utiču na postizanje optimalne zaštite i vaspitanja djece do tri godine starosti (ostvarenje vizije putem misije).

\section{Vizija i misija}

Predškolski radnici fokus grupe izveli su idealizovanu projekciju vaspitanja djece do tri godine u predškolskim ustanovama Bosne i Hercegovine u budućnosti - viziju i način kako do nje doći - misiju.

\section{Vizija}

Vaspitačka idealizovana projekcija vaspitanja djece do tri godine u Bosne i Hercegovine u budućnosti realizuje se u izuzetno povoljnoj materijalnoj i socijalnoj sredini. Ta sredina može biti bebina primarna porodica i idealna predškolska institucija.

1. Ako dijete do tri godine ima funkcionalne i optimalne uslove za razvoj u primarnoj porodici cilj je da u prvim godinama života bude $s$ majkom koliko je god moguće i da s njom ostvari sigurnu afektivnu vezu. O značaju adekvatnih primarnih vezanosti i potrebe socijalne stimulacije malog djeteta od strane majke govore brojna istraživanja (Bowlby 1965; Stewart i Joins 2011). Ovakvi roditelji bi trebali dobiti maksimalnu stručnu podršku (Roberts 2009).

2. Ako je majka zaposlena i/ili dijete živi u depriviranoj sredini (materijalno i/ili soc-emocionalno) potrebno je da pohađa predškolsku ustanovu. Nedostatak optimalne podrške u primarnoj porodici beba može nadoknaditi u jaslenoj grupi. To je naročito bitno za djecu marginalizovanih grupe, u prilog čemu govore brojna istraživanja pozitivne prakse (Barnett 2008; Stojaković 2000). Ulaganje u najmlađe je najefikasnije 
ulaganje u ljudske resurse, dugoročno je isplatljivo i samoobnovljivo (Heckman 2013), a najisplatljivije je za bebe koje žive u nepovoljnim porodičnim prilikama.

3. Pored socijalnog faktora vaspitanje djece do tri godine zahtijeva i bolju organizaciju rada ustanove, kao i kvalitetniju kadrovsku obučenost.

4. Vrtić budućnosti je podržan sa svih državnih i društvenih nivoa, jer su svi članovi društva svjesni značaja zaštite i ranog vaspitanja.

\section{Misija}

Uvažavajući realne društvene, kulturne, političke, ekonomske i socijalne aspekte koji uslovljavaju ostvarenje njihove vizije, vaspitači fokus grupe su iznijeli svoje viđenje rješenja. Ono se ogleda u razvijanju i unapređenju predškolskog vaspitanja djece do tri godine u skladu sa savremenim naučnim saznanjima i dobrom praksom.

1. Podrška u sferi osnaživanja roditeljstva i razvoja malog djeteta treba da bude pružena u zakonskom, prostornom, materijalnom, finansijskom, programskom, stručnom, savjetodavnom, zdravstvenom, socijalnom, vaspitno-obrazovnom smislu.

2. Obzirom da je u BiH zastupljeno dječije siromaštvo bitno je svu siromašnu djecu, naročito bebe, obuhvatiti predškoskim programom. To podrazumjeva veća ulaganja u predškolstvo od strane nadležnih institucija (drugačija preraspodjela sredstava), finansiranje od strane lokalne zajednice ne samo javnih nego i privatnih vrtića. Potrebno je omogućiti besplatnu uslugu za svu siromašnu djecu, kao i umanjenje cijene vrtića porodicama sa nižim prihodima. To zahtjeva formiranje platnih razreda finansija roditelja i određivanje visine participacije za vrtić. Komparativno proučavanje dobre vaspitne prakse i organizacionih rješenja predškolskih programa u drugim državama glede obuhvata siromašne djece takođe je jedan od zadataka misije. Potrebno je osmisliti nove predškolske programe i organizovati nove oblike predškolskih ustanova: putujuće vrtiće, mobilne vrtiće i mobilne timove volontera studenata-vaspitača, eko, šumske i vrtiće u prirodi koji bi omogućili obuhvat djece iz ruralnog područja gdje je naglašenije siromaštvo, a predškolske ustanove malobrojne. Poznato je da su neki od veoma uspješnih vaspino-obrazovnih pravaca upravo i opstali zahvaljujući naporima i podršci porodica u vrijeme siromaštva, poput programa Reggo Emillio (Gardner 2005) koji je nastao u teškim postratnim godinama u Italiji iz stava da su najmlađi zajednička odgovornost cijele za- 
jednice. Nezaposlenost, siromaštvo i dječije razvojne poteškoće podstakli su vaspitača, učitelje i roditelje (mahom iz italijanskih sela) da djeluju skupa te su upravo zahvaljujući svojoj otvorenost prema socijalnoj sredini ove ustanove i opstale. Obzirom da su najugroženija djeca u BiH uglavnom iz višečlanih porodica, nedovoljno obrazovanih i nezaposlenih roditelja, gdje više generacija živi skupa (Iniciativa za bolju i humaniju inkluziju 2013) pomoć djeci bi se mogla pružiti i kroz edukaciju i obrazovanje drugih članova porodice. Edukacija roditelja je veoma korisna (Roberts 2009), uključivanje porodica u v/o program, adekvatna komunikacija i interakcija samo su još neke od ideja o kojima bi trebalo promišljati jer su se pokazale podsticajne u nekim kulturama (Devjak, Novak i Lepičnik Vodopivec 2009, 204-205). Ovakvi napori trebali bi doprinjeti ostvarenje jednakih mogućnosti za sve bebe na području BiH. Takođe, bitno je inicirati i informisati domaće i inostrane donatore, osmisliti i/ili se priključiti predškolskim projektima koji bi omogućili proširenje mreže predškolskih ustanova i besplatno predškolsko vaspitanje najmlađih iz ugroženih porodica.

3. Vaspitačice fokus grupe smatraju da je bitno ispuniti određene organizacione uslove u ustanovi manji broj djece u grupi, homogene jasličke grupe, duži vremenski period boravka oba vaspitača u grupi, tri radnika u jaslenoj grupi, personalni asistent $u$ grupi za dijete $s$ poteškoćama, obavezan medicinski radnik za grupu, a pedijatar za vrtić, pojačan savjetodavni rad stručnih saradnika s roditeljima, uključivanje roditelja i baka i djedova u vaspitni rad vrtića, poštovanje pravila dovođenja zdrave djece u vrtić, obavezna soba za izolaciju za bolesnu djecu. Takođe, bitno je usavršiti i proširiti pedagoška, metodička, zdravstveno-higijenska znanja predškolskih radnika za rad s bebama u vrtićima. To podrazumijeva modernizovati programske koncepcije, poboljšati stručnu osposobljenost za rad s bebama uvodeći dodatne predmete za njegu i vaspitanje beba na Studijskim programima za predškolsko vaspitanje, uvesti studentsku praksu u vrtićima specijalno u jaslenim grupama, povećati broj seminara i intenzivirati stručno usavršavanje vaspitača za rad s bebama, poboljšati razmjenu iskustava dobre prakse; istraživati vaspitni rad u jaslicama. Vaspitači fokus grupe pokazuju spremnost za dodatno stručno usavršavanje iz ove oblasti s ciljem ostvarivanja efikasnije podrške bebinom razvoju. Unatoč važnosti prvih godina života, nedovoljno pažnje im se posvećuje i u naučnonastavnom programu, kako na dodiplomskom i postdiplomskom studiju tako i na obaveznim edukacijama vaspitača. lako postoje brojni 
metodički pristupi i načini u radu s jaslenom djecom koji su efikasni i lako ispitljivi u našim predškolskim ustanovama (Rajović, Šindić i Suzić 2015; Rajović, Šindić i Čampara 2014) mali broj naučnih radova je na tu temu, što se svakako može i treba promijeniti.

4. Da bi se postigle povoljne sredinske prilike za optimalan rad i djelovanje predškolskih ustanova potrebno je da su svi članovi društva svjesni značaja ranog razvoja i učenja za pojedinca i čitavu državu. Nažalost, u Bosni i Hercegovini svjest o tome je na veoma niskom nivou. Zato je potrebno raditi na edukaciji i senzibilizaciji bosansko-hercegovačkog društva o značaju ranog djetinjstva i podrške holističkom razvoju djece do tri godine starosti. To povlači za sobom uključivanje u ovu problematiku nadležne institucije izvan predškolske ustanove (ministarstvo, prosvjetno pedagoški zavod, visokoškolske ustanove, medije, naučne, socijalne i zakonodavne institucije).

\section{Interna i eksterna analiza}

Putem interne i eksterne analize trebalo je izdvojiti i sagledati prednosti, atribute i pretpostavke (strenghts) i slabosti (weaknesses) vrtića i predškolskog kadra, s jedne strane, te mogućnosti i povoljne prilike (oportunities) i ograničenja (threats) roditelja i zajednice, s druge strane (preglednica 1). Nastojalo se odgovoriti na pitanja kako iskoristiti snage predškolske ustanove, roditelja i šire zajednice, te kako izbjeći i ublažiti nepovoljne uticaje i ograničenja predškolske ustanove, porodice i šire društvene sredine u kontekstu ranog razvoja i učenja, $\mathrm{tj}$. unapređenja vaspitanja djece do tri godine.

Kao što se vidi u tabelii 1, vaspitači su izdvojili jake i slabe strane predškolske ustanove i društvene zajednice bitne za strateški razvoj vaspitanja djece do tri godine. Naveli su i nekoliko prijedloga kako ublažiti poteškoće. Uočavaju da je neophodna edukacija roditelja i društva o ranom djetinjstvu, značaju vaspitanja i obrazovanja na ranom uzrastu. Potrebno je informisati javnost o tome da rani obuhvat djece iz rizičnih siromašnih porodica neutrališe uticaja nepovoljnih porodičnih prilika na razvoj beba i male djece (siromaštvo, nažalost, postaje naglašen društveni problem). Naglašava se potreba informisanja roditelja i javnosti o radu predškolskih ustanova i potrebama šireg obuhvata djece institucionalizovanim predškolskim vaspitanjem i obrazovanjem, uspostavljanje zakonskih akata kojima će se apostrofirati značaj prvog stepena vaspitno-obrazovnog sistema i inicirati materijalna ulaganja u ovoj oblasti života i rada, obezbjediti besplatno pohađanje vrtića siromašnoj djeci i smanjene troškove vrtića određenim kategorijama djece. Bitno je organizovati i edukaciju roditelja o roditeljstvu, adekvatnom vaspitanju djece do tri 
Tabela 1 Interna i eksterna analiza

\begin{tabular}{lll}
\hline \multirow{2}{*}{$\begin{array}{l}\text { Interni } \\
\text { elementi }\end{array}$} & Snage & Slabosti \\
\cline { 2 - 3 } & Školovan i stručan kadar: vaspitači, & Nedostatak kadra: pedijatrijskih se- \\
& stručni saradnici; entuzijazam i krea- & stara, ljekara pedijatra, psihologa, pe- \\
& tivnost v/o radnika; saradnja, timski & dagoga i socijalnih radnika; slabija pri- \\
rad u vrtiću i razmjena iskustava pozi- & premljenost studenata za rad s djecom \\
tivne prakse; adekvatna oprema, mate- & do tri godine u odnosu na uzrast od 3- \\
rijal i prostor za igru i iskustveno uče- & 6 godina; zanemareno stručno usavr- \\
nje beba; inkluzija. & šavanje (propisano od nadležnih insti- \\
& tucija - Ministarstva, Pedagoškog za- \\
& voda i sl.) i nedostatak v/o seminara za \\
& uzrast do tri godine, nedovoljno pro- \\
& jekata (u odnosu na uzrast 3-6); nedo- \\
& voljno razrađen program za rad s dje- \\
& com do tri godine.
\end{tabular}

\begin{tabular}{|c|c|c|}
\hline & Povoljne prilike & Prijetnje \\
\hline $\begin{array}{l}\text { Eksterni } \\
\text { elementi }\end{array}$ & $\begin{array}{l}\text { Mogućnost preraspodjele budžet- } \\
\text { skih sredstava u korist najmlađih ko- } \\
\text { risnika; podrška domaćih i stranih do- } \\
\text { natora, UNICEFa i sl.; zainteresovanost } \\
\text { porodice za djecu: majke, oca, bake i } \\
\text { dede ...; spremnost članova porodice } \\
\text { da budu pomagači i volonteri u v/o } \\
\text { procesu; pomoć studenata na univer- } \\
\text { zitetskoj praksi; studenti i vaspitači vo- } \\
\text { lonteri; personalni asistenti koje rodite- } \\
\text { lji angažuju za pomoć pri radu; sarad- } \\
\text { nja sa institucijama: dom zdravlja, pe- } \\
\text { dagoški zavod, fakultet, centar za so- } \\
\text { cijalni rad, nadležna ministarstva i za- } \\
\text { konodavna tijela, opština - osnivač i } \\
\text { sl.; promovisanje i podrška predškol- } \\
\text { skih ustanova, edukacija i senzibiliza- } \\
\text { cija javnosti o ranom djetinjstvu u me- } \\
\text { dijima kroz edukativne emisije o pred- } \\
\text { školstvu. }\end{array}$ & $\begin{array}{l}\text { Ekonomska i politička kriza u zemlji; loš } \\
\text { kvalitet života i loša društvena atmo- } \\
\text { sfera; nedovoljna budžetska sredstva; } \\
\text { visoke cijene vrtića u odnosu na plate- } \\
\text { žnu moć roditelja; šire društveno nera- } \\
\text { zumjevanje i neosjetljivost za pitanje } \\
\text { najmlađih, neznanje o značaju prvih } \\
\text { godina života za razvoj čovjeka i ne- } \\
\text { zainteresovanost; neprovođenje i neu- } \\
\text { sklađenost zakonskih propisa; mediji u } \\
\text { podršci manipulaciji, širenju nekulture } \\
\text { i neznanja i senzacija; nedovoljna po- } \\
\text { drška mladim porodicama (u edukaciji, } \\
\text { materijalnoj i stručnoj pomoći). }\end{array}$ \\
\hline
\end{tabular}

godine, evolutivno podržavajućim aktivnostima, različitim dječijim poteškoćama, komunikaciji isl, organizovati redovne savjetodavne razgovore roditelja djece s poteškoćama integrisane u grupu s timovima stručnjaka, vaspitača i menadžmenta predškolske ustanove.

\section{Zaključak}

Vaspitanje i obrazovanje djece je društveno uslovljen fenomen. Kada su prilike u nekom društvu nepovoljne, ako se ne iznađu adekvatne mjere i pra- 
vovremeno se ne odreaguje, najugroženiji su oni najranjiviji i najmlađi članovi društva. Država koja ulaže dovoljno sredstava u najmlađe, osigurava i podržava svoju budućnost - djecu. Dakle, u interesu svih članova društva je da se osigura dobar start svakoj bebi (Heckman 2013), što bi trebao biti posebno značajan zadatak u svim državama u kojima su nepovoljne ekonomske prilike. Mada mnoge uskraćenosti na ranom uzrastu koje ometaju razvoj cjelokupne djetinje ličnosti nisu finansijske prirode (Bowlby 1965; Jovanović Madyar 2008; Stewart i Joins 2011), potrebno je posebnu pažnju posvetiti činjenici da je stopa siromašne djece u Bosni i Hercegovini visoka. Prema podacima Agencije za statistiku Bosne i Hercegovine (2013), u 2011. godini 30,5\% djece živi u siromaštvu, a među njima su najbrojnija djeca koja žive u ruralnim oblastima, u višečlanim porodicama, gdje roditelji imaju skromno obrazovanje i mahom su nezaposleni. Takođe, ono što je specifično za ovu zemlju je izuzetno niska stopa obuhvata djece predškolskim ustanovama (oko $14 \%$ djece do šest godina idu u vrtić, a 4,44\% djece do tri godine pohađa vrtić) (Agencija za statistiku Bosne i Hercegovine 2017; 2018). Obuhvat djece iz rizičnih skupina je neznatan.

Da bih futurološki sagledala strateške razvojne elemente vaspitanja djece do tri godine u Bosni i Hercegovini pristupila sam SWOT-analizi. Nastojala sam timski istražiti i dugoročno sagledati vaspitanje djece do tri godine $u \mathrm{BiH}$ iz ugla predškolskih radnika, njihovu viziju optimalne podrške najmlađima, ranom razvoju i učenju, promišljanje o tome kako je ostvariti, organizovati i metodički oblikovati te predispozicije i ograničenja za to. Ono što vaspitači vide kao viziju kojoj treba stremiti je veći obuhvat djece predškolskim vaspitanjem u BiH i besplatno uključivanje sve djece iz rizičnih skupina institucionalizovanim predškolskim programima. Glavno oruđe na tom putu je senzibilizacija javnosti i edukacija o značaju i specifičnosti ranog djetinjstva, informisanje društva i pojedinaca s ciljem optimalnije preraspodjele sredstava budžeta, ulaganja i donacija, donošenja i primjena adekvatne vaspitnoobrazovne strategije i zakonske regulative. Takođe, vaspitači uočavaju potrebu bolje organizacije rada sa bebama u predškolskim ustanovama, dodatnog stručnog obrazovanja studenata i vaspitača za vaspitanje djece do tri godine starosti i naglašenije uključivanje porodice u vaspitno-obrazovni proces, osavremenjavanje dijela Programa predškolskog vaspitanja i obrazovanja (2007) koji se odnosi na uzrast do tri godine i sl.

U mnogim evropskim zemljama je prepoznat značaj predškolske ustanove i vaspitanja za djecu do tri godine što rezultire visokom stopom uključenosti djece u predškolske programe u prvom starosnom dobu (od završetka porodiljskog odsustva pa do tri godine starosti) u tim državama (Hočevar i Kovač 
Šebart 2017). Vaspitači iz fokus grupe prepoznaju svoju ulogu za unapređenje podrške dječijem razvoju. Pored dodatnog stručnog usavršavanja i istraživanja, osavremenjavanja i obogaćivanja vaspitne prakse s bebama, organizovanja raznih oblika programa predškolskog vaspitanja (kao dopunu osnovnim), ističe se i promovisanje vlastite struke i vlastitog rada kao i nastojanje senzibilizacije društvene zajednice o značaju ranog razvoja i potrebi ranog obuhata djece institucionalizovanim predškolskim vaspitanjem slijedeći dobre primjere razvijenih evropskih zemalja.

\section{Bibliografija}

Agencija za statistiku Bosne i Hercegovine. 2013. Anketa o potrošnji domaćinstava u BiH 2011. Sarajevo: Agencija za statistiku Bosne i Hercegovine.

— 2017. Bosna i Hercegovina u brojevima 2017. Sarajevo: Agencija za statistiku Bosne i Hercegovine.

Agencija za statistiku Bosne i Hercegovine. 2018. „Statistika obrazovanja.« Saopćenje 13 (2): 1.

Barnet, W. S. 2008. »Preschool Education and Its Lasting Effects: Research and Policy Implications.«http://greatlakescenter.org/docs/Policy_Briefs/ Barnett_EarlyEd.pdf

Bowlby, J. 1965. Child Care and the Growth of Love. London: Penguin Books.

- 1995. Maternal Care and Mental Health. London: Jason Aronson.

Camović, Dž., i L. Hodžić. 2017. »Analiza stanja na področjo predšolske vzgoje v Bosni in Hercegovini z vidika pravičnosti in enakih možnosti za vse otroke." Sodobna pedagogika 68 (3): 28-45.

Devjak, T., L. Novak i J. Lepičnik Vodopivec. 2009. »Kakovostna interakcija in komunikacija."U Izzivi pedagoškega koncepta Reggio Emilia, ur. T. Devjak i D. Skulic. 189-207. Ljubljana: Pedagoška fakulteta.

Diamond, M. 2001. »Response of the Brain to Enrichment.« Annals of the Brazilian Academy of Sciences 73 (2): 211-222.

Gardner, H. 2005. Disciplinirani um. Zagreb: Educa.

Greber, M., i A. Johnson. 1997. Your Self-Confident Baby. New York: Wiley.

Heckman, J. 2013. Giving Kids a Fair Chance. Boston, MA: MIT Press.

Hočevar, A., i M. Kovač Šebart. 2017. »Pravičnost in dostopnost predšolske vzgoje v državah nekdanje Jugoslavije: skupna zgodovina, različne možnosti.« Sodobna pedagogika 68 (3): 8-27.

Iniciativa za bolju i humaniju inkluziju. 2013. »Siromaštvo u BiH 2011 - trendovi i dostignuća 2013."http://www.ibhi.ba/Documents/Publikacije/2013/ IBHI_Siromastvo_u_BIH_2011_Trendovi_i_dostignuca.pdf

Jovanović Magyar, A. 2008. Zašto to radiš? Beograd: Centar za primenjenu psihologiju.

Konvencija o ljudskim pravima. 1950. https://www.echr.coe.int/Documents/ Convention_SRP.pdf 
Konvencija o pravima djeteta. 1989. http://ombudsman.co.me/djeca/docs/ konvencijaopravimadjeteta.doc

Kordeš Demšar, M. 2007. »Pedagogika Montessori.«Sodobna pedagogika 58 (4): 80-91.

Montesori, M. 2003. Upijajući um. Beograd: DN Centar.

Okvirni zakon o predškolskom odgoju i obrazovanju u Bosni i Hercegovini. 2018. Službeni glasnik Bosne i Hercegovine, br. 12.

Papić, Ž. 2017. Siromaštvo i radničko siromaštvo u BiH. Sarajevo: Forum lijeve inicijative.

Rajović, R. 2010. Metodički priručnik za vaspitače. Vršac: Visoka škola strukovnih studija za obrazovanje vaspitača Mihajlo Pavlov.

Rajović, R., A. Šindić i D. Čampara. 2014. "NTC program na jasličkom uzrastu.« U Kvalitet vaspitno-obrazovnog rada: zbornik radova 2. skupa pedagoga, ur. M. Ilić, 145-159. Banja Luka: Društvo pedagoga RS.

Rajović, R., A. Šindić i N. Suzić. 2015. »Habit of Solid Food Conformmation Preschool-Aged Children and Its Potential Role in Cognitive Development. « U Vzgojno-izobraževalne perspektive: obzorja učenja, ur. T. Grušovnik, 378-393. Koper: Univerza na Primorskem.

Roberts, K. 2009. Early Home Learning Matters. London: Family and Parenting Institute.

Slunjski, E. 2011. Kurikulum ranog odgoja. Zagreb: Školska knjiga.

Suzić, N. 2012. Futurologija. Banja Luka: Ektos.

Stewart, I., i V. Joins. 2011. Savremena transakciona analiza. Novi Sad: Psihopolis institut.

Stojaković, P. 2000. Darovitost i kreativnost. Srpsko Sarajevo: Zavod za udžbenike i nastavna sredstva Republike Srpske.

Šindić, A. 2018. Upoznavanje predškolske djece s okolinom i društvenom sredinom. Banja Luka: Filozofski fakultet.

Ustav Bosne i Hercegovine. 1995. http://www.ccbh.ba/public/down/USTAV _BOSNE_I_HERCEGOVINE_srp.pdf

\section{Perspektive vzgoje otrok prvega starostnega obdobja v Bosni in Hercegovini}

Raziskavo so spodbudila protislovja med sodobnimi znanstvenimi raziskovanji in trendi, ki kažejo na odločilen vpliv zgodnjega otroštva in podpore najmlajšim otrokom na razvoj osebnosti in družbe, ter realnost predšolske vzgoje v BiH. S kvalitativno analizo SWOT, z vstopanjem na področje pedagoške futurologije, smo poskusili raziskati in dolgoročno opredeliti strateške komponente razvoja ter organizacije vzgoje otrok v prvem starostnem obdobju v $\mathrm{BiH}$, in sicer s stališča vzgojiteljev. Cilji raziskave so ugotovljanje vizije vzgojiteljev, razumevanje misije vrtca ter prikaz internih in eksternih možnosti ter ovir za optimalno organizacijo predšolske vzgoje otrok v prvem starostnem 
obdobju. Za uresničenje ciljev misije vrtca - ti so povečanje števila otrok v oddelkih, $v$ različnih programih, s poudarkom na otrocih iz depriviligiranih družin - morajo vzgojitelji prepoznati svoje naloge. Poleg dodatnega strokovnega usposabljanja in raziskovanja, posodabljanja in bogatenja vzgojne prakse je potrebno izpostaviti tudi promoviranje stroke ter dela kot tudi senzibilizacijo družbe glede pomena zgodnjega otroštva.

Keywords: vzgoja, otroci prvega starostnega obdobja, enake možnosti 